\title{
Developing Scientific Writing Instruction Evaluation Instrument by Using Constructivism Approach
}

\author{
Supriyadi \\ Program Studi Pendidikan Bahasa dan Sastra Indonesia \\ Universitas Negeri Gorontalo \\ supriyadiung@yahoo.co.id
}

\begin{abstract}
The aim of this research was to develop evaluation instruments for scientific writing instruction with a constructivism approach. In order to achieve the research objectives, the combined models of development, 4D and RDR were used. The design of this research that included four stages, namely the preliminary study, define, design, and development. The research data were quantitative and qualitative. Data analysis techniques were the domain technique and $t$ test statistical. Based on the results, the obtained development product in the form of the evaluation of the instruction of writing scientific papers were valid and reliable. The development product consisted of four types of evaluation devices, the assessment rubrics, portfolios, observation sheets, and learning journal. Based on the results of the four development products, the effectiveness test was valid and reliable so that it can be used to conduct evaluation of learning to write scientific papers with constructivism approach, both for the evaluation of the process and the evaluation of the learning outcomes. The result of this development research implies that the product of this development research was valid and reliable, and feasible and reliable for using in scientific writing instruction because haved been through a lengthy development process and systematically.
\end{abstract}

Keywords-constructivism, development, evaluation instrument, learning, scientific writing

\section{INTRODUCTION}

Evaluation is a series of activities to acquire, analyze, and interpret data about the process and results of student learning which is done systematically and continuously, so that the result will give meaningful information in decision-making [1]. The evaluation is done during and/or at the end of the the learning process. The focus of the evaluation is the student learning success in achieving competency standards and indicators of achievement that have been determined. Evaluation is an important part of learning [2].

With an evaluation, a lecturer as a manager of the learning process can determine the capabilities of the students, the suitability of the teaching methods used, and the success of students in achieving predetermined competence [3]. Based on the evaluation, teachers can make appropriate decisions to determine what to do next. The evaluation results can also motivate students to perform better.

An evaluation should have a high principle of fairness [4] [5]. That is, students are treated equally, thus it does not harm anyone or group of students being evaluated. In addition, the evaluation does not distinguish between the social, economic, cultural, language, gender, and religious backgrounds. An evaluation is also a part of the educational process to encourage and motivate students to perform better in achieving the highest level according to their ability [5] [6].

By adhering to the important role of evaluation in the learning process, including the teaching of writing scientific composition, the instrument used to perform the evaluation process should be developed systematically and well-planned in order to accurately measure what should be measured [7]. The instrument resulting from the development is called an evaluation instrument of development product. The evaluation instrument of development product is a valid and reliable instrument to be used because it has been through a series of tests, namely the practitioner test, expert test, a small group test, and la rge group test.

Pertaining to the issue that learning to write scientific compositions has an important role for the smoothness and completion of the student study in higher education [8], the evaluation instruments need to be developed. It was based on the results of preliminary studies that the existing evaluation instruments were still based on the traditional approach, lacking support in the implementation process and the achievement of learning outcomes, not being able to increase students' physical and psychological activity, and only measured the knowledge and skills of the students in writing scientific papers.

The evaluation instrument developed for writing scientific composition is oriented or based on a constructivism approach in line with the approach used in the learning process. The constructivism evaluation instrument is capable of stimulating students' learning by constructing the knowledge and skills learned by the students themselves through intensive interaction with the material, study groups, communities and the surrounding environment [9]. There are four types of evaluation instruments developed in this study, they are the assessment rubrics, portfolios, observation sheets, and learning journal.

The benefits that can be gained from the development of evaluation instruments of learning to write scientific papers is that the learning spirit of student can be improved by the increasing physical and psychological activity of the students; students are familiar with the learning patterns of constructing knowledge and skills learned independently; it makes students 
have sensitivity towards the material being studied, the study groups, the communities, and the environment; it makes students have a democratic attitude; tolerance; willing to give and accept the opinions of others; discipline, responsibility; honest, and other noble attitudes required in learning [10]. The development product can also help students in the learning process, as guidelines and learning resources that can assist them in learning to write scientific composition, and can develop the students' inspiration, motivation, creativity, productivity, and the power of reason in writing scientific compositions.

In addition, the product of this development can be beneficial to lecturers, book authors, as well as material and curriculum developers. The benefit for lecturers is that the product of this development can be used as a reference / guide for carrying out the process of learning to write scientific compositions and evaluation process with a constructivism approach. The benefit for authors of books/teaching materials is that this can be a sort of material to be considered in setting evaluation instrument of learning with a constructivism approach. The benefit for curriculum developers is that it is one of the inputs that the lecturers must do and for them to see the condition of the learning and evaluation needs in the field.

\section{METHOD}

The development model used in this study was Define, Design, Development, and Dissemination Model [11] known by the acronym as 4D and Research Development Research [12] known by the acronym as RDR. The 4D model consisted of four activities, i.e. define, design, development, and dissemination or distribution activities. The dissemination activity was not carried out because of the dissemination process required a very broad sphere. Meanwhile, in the model of the RDR, there were three activities, namely the activities of a preliminary study, development, and implementation of effectiveness test.

The procedure of the development product was embodied in the form of activities. There were four activities carried out, i.e. preliminary study, define, design, and product development. The first activity - the preliminary study - was conducted to obtain early information about requirements, field conditions, and eligibility to develop evaluation instrument of learning. The preliminary study was also intended to set up the collaboration with the lecturers responsible for the course. The preliminary study results were used to design and develop products.

The second activity of the development process was conducting the determination. The determination activity was done by determining the product developed and establishing a participatory team. The determination is made to establish two things: the products developed and the establishment of a participatory team. First, the product developed was in the form of evaluation instrument of learning to write scientific papers with a constructivism approach. The product developed was packaged in the form of printed materials consisting of four types, namely the assessment rubrics, portfolios, observation sheets, and learning journal. Second, a participatory team whose members worked in the development process was formed. The team consisted of students, lecturers, practitioners, and experts in relevant fields of study.

The third activity of the development process was to perform product design. The product design process was done in collaboration with the lecturers and students. Product design began with a preliminary study or need analysis. A pilot study was conducted to obtain preliminary information on the situation and the condition of the field feasibility, the necessity and feasibility of development product. The preliminary studies were also conducted to explore collaboration with the lecturers and the students.

The fourth activity of the development process was to conduct the development of the product that had been designed. The development product process was done through four test stages, namely the practitioner test, the test of expert relevant to the field of study, the small group test with 8 students, and the large groups test with one class of students, comprising of 35 students.

The data source of this research was practitioners, experts, students, and the learning process. Data from practitioners and experts were in the form of comments, criticisms, suggestions, corrections, and assessment of learning evaluation instrument products of scientific writing. Data from students were in the form of oral and written speech, behavior, attitudes of students in the learning process, and scores of scientific work of students before and after the learning process. Data from the lecturers were in the form of oral and written speech, behavior, attitudes in the learning process, learning evaluation instrument documents, comments, criticisms, suggestions, corrections, and assessment of learning evaluation instrument products write scientific papers. On the other hand, the data of the learning process at the time of testing were the effectiveness of a pattern of interaction between students and students, students with lecturers, students with material, student participation in the learning process, and reflecting on learning [13].

Data analysis were divided into three, namely data analysis of the results of expert and practitioner test, data analysis while testing the product, and data analysis of the results of product effectiveness test. The data analysis of practitioner testing, expert testing, field testing was done by using domain analysis [14]. The data were grouped by content, format, and language domains based on the evaluation instrument being developed, namely the assessment rubrics, portfolios, observation sheets, and learning journal. The data of each domain were reflected to draw conclusions on the outcome of the analysis. The conclusions based on the results of the analysis were used to revise the learning evaluation instrument to write scientific papers.

The data analysis of the product tryout was conducted on the students'speech, behavior, attitudes in the learning process, and the scientific work. In addition, the data analysis during field tryout was also conducted on the lecturers'speech, 
behavior, attitude in the learning process, learning evaluation, comments, criticisms, suggestions, corrections, and the lecturers' assessment on the product of evaluation instrument to write scientific papers. The results of the data analysis during the field tryout were used to revise the product on an ongoing basis to obtain a solid development product.

The data analysis of the product effectiveness testing was carried out by statistical analysis. The difference in scores of the pretest and posttest of the learning process using a development product was performed through dependent sample $\mathrm{t}$ test. The statistical data analysis of the product effectiveness test results was performed using SPSS 18.0 for Windows [15].

\section{RESULTS AND DISCUSSION}

The development of evaluation instrument with a constructivism approach was intended to improve the writing skills of the students in scientific composition. The evaluation instrument developed was approved to be based on the adaptation of the evaluation instrument of learning by the Education Ministry in 2008, feedback from lecturers, the ease of implementation in the learning process, and the format indicating the learning with a constructivism approach. The evaluation process was carried out integratedly with the learning process to assess the implementation of the learning process and was carried out separately when used to evaluate learning outcomes in the form of scientific composition of students. The developed evaluation instrument for writing scientific papers was divided into four types, namely the assessment rubrics, portfolios, observation sheets, and learning journal.

The development of evaluation instrument was meant to conduct evaluation process of scientific writing instruction. The evaluation is a series of activities to acquire, analyze, and interpret data about the process and results of student learning which is carried out systematically and continuously so that it will be meaningful information in decision making. The evaluation is done during the learning process or at the end of the learning process. The focus of the evaluation is the success of the students in achieving basic competence and the determined indicators of achievement, especially in scientific writing.

Evaluation is an important part of learning. By conducting the evaluation, teachers can know the capabilities of the students, the accuracy of the learning methods used, and the success of students in achieving stipulated competence. Based on the evaluation, the teachers can make decisions appropriately to determine what to do next. The evaluation results can also provide motivation for students to perform better.

An evaluation should have a principle of fairness. Students are treated the same so it does not harm any one or group of students being evaluated. An evaluation does not distinguish between the social, economic, cultural , language, gender, and religion. An evaluation is also a part of the educational process to encourage and motivate students to perform better in order to achieve a high level according to his ability.

In terms of lecturers' professionalism, evaluation is one of the characteristics of professional lecturers. Professional lecturers always want feedback on the learning process they do. This is done because one of the indicators of the success of learning is determined by the level of success achieved by the students. Thus, the evaluation results can be used as a benchmark for the success of learning and feedback process for lecturers to improve the quality of their lessons.

In connection with the above description, in this study four instruments evaluation of learning were developed for the sake of ratings in order to improve the skills of students in scientific writing, as well as the quality of the process, and the quality of learning outcomes. The four instruments of such evaluation were the assessment rubric, portfolio, observation sheets, and learning journal that have the characteristics of constructivism. The development of the four evaluation instruments were based on a constructivism approach. That is, a constructivism approach is used as a reference in developing an evaluation instrument. The characteristics of the four developed evaluation instruments of learning referred to the evaluation of individual development product instrument. Each learning evaluation instrument developed has different characteristics.

First, the characteristics of the type of scoring rubric of evaluation instrument consist of five indicators with a number of descriptors and scoring weights. The evaluation instrument used to evaluate the quality of the scientific work of students consisted of five indicators, namely the title selection, development ideas/content, organization ideas/content, presentation techniques, and the use of language. Secondly, the characteristics of the type of portfolio evaluation instrument consisted of two components, namely the identity of a portfolio that included the objective, type of portfolio, semester, time frames, and the name of the student, and the contents of the portfolio that included tasks and evidence that had to be collected and concluded from evaluation results. Third, the characteristics of the type of evaluation instrument observation sheet consisted of three components, namely the identity of observation sheets, user manuals, and a list of questions. Lastly, the fourth, the characteristics of the type of learning journal of evaluation instrument consists of two components, namely the identity of the journal and the reflection on learning.

The four learning evaluation instruments developed were based on the adaptation of the format of evaluation instrument by the result of collaboration with lecturers advisers, examples of evaluation instruments of learning to write scientific papers, and their ease of implementation in the process of learner's, and the characteristics of learning with a constructivism approach.The characteristics of learning with a constructivism approach were seen from the authenticity of the four types of learning evaluation instruments when implemented in an integrated manner in the learning process. The evaluation of the learning process was carried out when students were 
participating actively in the learning process. The evaluation process was carried out in an integrated manner with the learning process and did not wait until the whole topic of learning was completely taught. The evaluation of the learning process was implemented using the evaluation instrument types of observation sheet and learning journal. The evaluation of the learning outcomes, ie scientific papers of the students was conducted by using the evaluation instrument types of assessment rubric and portfolio.

The learning evaluation instrument in this study was developed based on the basic competencies and indicator of success. It was intended that the evaluation of learning was none other than measuring the level of achievement of the basic competencies and indicators that had been set. The description of the learning evaluation instruments can be observed more completely in the development product evaluation instrument.

The next step that the fourth evaluation instruments were to test of effectiveness. The test of the effectiveness of the development product was intended for the purpose of obtaining information about the effectiveness of development product in the form of the evaluation instruments of learning to write scientific papers in the learning process. The effectiveness test was carried out by performing tests of students' different achievement before and after the learning process by using development product. The students' achievement in learning to write scientific papers was manifested in the form of score. The design was a single group pretest and posttest design.

Based on the statistical test was obtained information that there was a difference between the scores of the pretest and the posttest on the process and result evaluation of learning to write scientific papers that utilized development product. The differences in scores were significant. The average score of the pretest in composing paper was 75.16 and the average score of the posttes in composing paper was 88.64. The average score of through the employment of the treatment, namely the use of the development product was 13.48. The result of paired samples $\mathrm{t}$ test was significant (two tailed) $\mathrm{p}=0.000<\dot{\alpha}=$ 0.005 .

That means that there are significant differences between the scores of the pretest and the posttest. Based on the results of these calculations it appears that the use of development product in the evaluation process and learning to write scientific papers significantly influence learning achievements of students to write scientific papers. Thus, it can be concluded that there is an increase in learning achievement of the students' writing scientific papers significantly between before and after the learning process of the learning process.

In connection with the results of the development presented earlier, in this study four learning evaluation instruments were developed to improve the writing skill of the students' in scientific work. The development of the evaluation instruments was based on a constructivism approach [16], meaning that the approach was used as a reference/guide in developing an evaluation instrument. The characteristics of the development of the evaluation instruments refer to each of the evaluation instruments. The characteristics of the evaluation instrument type of rubric consist of five indicators with a number of descriptors and scoring weights were used to evaluate the quality of the scientific work of the students. The five indicators were the title selection, the development of ideas/content, the organization of ideas/content, the presentation techniques, and the use of language. The characteristics of the type of portfolio evaluation instrument consists of two components, namely the identity of the portfolio, which included the contents of the portfolio tasks and evidence that must be collected and the conclusions of the evaluation results. The characteristics of the evaluation instrument type of observation sheet consisted of three components, namely the identity of the assessors, the evaluation instructions, and the list of questions relating to the observed target. The characteristics of learning evaluation instrument type of learning journal consisted of two components, namely the identity of the journal and the reflection. The reflection contained any of a number of questions used to carry out the process of the interospection towards the learning that had been implemented.

The spirit of constructivism in the evaluation instrument development product can be seen in all four types of the evaluation instruments when used in the learning process. The four evaluation instruments can be utilized to evaluate as well as to train students to develop the knowledge and skills being learned. In building the knowledge and skills to write scientific papers, the students can work together in study groups, be responsible for solving the tasks of learning, present the results of the work, ask questions, and reflection. All of them are learning processes that have the soul of constructivism approach [17] [18]. These four types of the evaluation instruments were developed by and for measuring process and result of learning to write scientific papers with a constructivism approach.

The learning evaluation instrument development was the result of adaptation of the format of an evaluation instrument by the feedback from lecturers, the ease of implementation in the learning process, and the format indicating the learning with a constructivism approach. The format indicating the constructivism learning approach was seen from the four types of learning evaluation instruments being developed. The format was designed to evaluate the process and outcomes of learning to write scientific papers that was integrated with the learning process so that the evaluation results could illustrate the overall ability of the students' academic potential. The evaluation of the learning process was implemented by using observation sheet type of the evaluation instruments and learned journals. The evaluation of the learning outcomes was implemented by using the section type of the evaluation instruments and portfolio assessment.

The development product of evaluation instrument was intended to improve the scientific writing skills of students and was designed for two types of evaluation; the learning process evaluation and the learning outcomes evaluation. The 
evaluation instrument to assess the learning process was embodied in the forms of observation sheets and learning journals, while the evaluation instrument to assess aspects of learning outcomes was embodied in the forms of assessment rubrics and portfolios .

Based on the effectiveness test, the development product in the form of four instruments evaluation of learning to write scientific papers was declared effective. The effectiveness test results was ( 2 tail) $p=0.000<\dot{\alpha}=0.005$. It signifies that the development product is appropriate to be used to perform evaluation activities, both for the evaluation of learning process and the evaluation of learning outcomes. The evaluation process was carried out during the process of learning to write scientific papers in progress, while the evaluation of the results performed to evaluate the learning outcomes of the students in scientific writing was in the form of papers.

The first type of evaluation instrument was used to measure/assess the level of participation, creativity, cooperation, responsibility, and mental involvement (emotional intelligence, enthusiasm, interest) of students in the learning process. The first evaluation instruments were also used to evaluate the performance of the lecturers during the learning process. The evaluation of the lecturers was conducted on the aspects of their involvement in helping, assisting, facilitating, motivating, and directing students to achieve learning goals. The second type of evaluation instrument was used to measure/assess students' learning outcomes in the form of the final task of the learning process. The final task of the process of learning to compose scientific piece of writing was in the form of papers.

The utilization of both types of the evaluation instruments that can encourage the increased interaction and the final process of learning to write scientific papers of the students. The utilization of the first type of the evaluation instruments can increase the intensity and quality of the students' work, their level of participation, creativity, cooperation, responsibility, involvement, psychological, ie, emotion, intelligence, enthusiasm, talents, and interests in the learning process. the utilization of the second type of the evaluation instruments is to improve the quality of the work in the form of student papers. [19] also suggests the use of instruments of evaluation process and evaluation of learning outcomes to improve the achievement of students. Thus, the estuary is the increasing in the students' scientific work writing skills.

This development product of evaluation instruments is used to motivate and improve learning outcomes of students in writing scientific papers. As stated up front that the evaluation instrument of learning process and results can be used to improve student achievement, especially the learning process evaluation instrument designed according to students' interests. The portfolio evaluation instrument, for example can be used to motivate student learning by collecting artifacts or the performance of students as many as possible into the portfolio document to complete learning tasks Likewise is applied for evaluation instrument types of observation sheet and learning journal.

The evaluation instrument of the development products can also be used as a guide for the learning process to write scientific papers. The process of learning to write scientific papers needs to be guided or needs specific guidelines to facilitate the students so that their skills in writing scientific papers continue to rise. That is, the steps to write scientific papers by the students are evaluated so that it can run properly in accordance with the procedure. The evaluation instrument of the development product is feasible to use as a guide for students in writing scientific papers.

These four types of the evaluation instrument of the development product can be used to guide students in writing scientific papers step by step. The portfolio evaluation instrument type, for example, is in the form of document collection of all the results of students' performance done step by step in writing scientific papers. When all the steps have been completed and all the tasks are collected in the portfolio file, the student has completed all the stages in writing scientific papers. Similar to the portfolio, the evaluation instrument type of assessment rubric contains a number of indicators that can lead the students in writing scientific papers properly.

In the evaluation instrument type of the observation sheet, there are components of student activity and lecturer activity in the learning process that need to be evaluated. The evaluation instrument type of observation sheet is used to record all activities in the forms of student participation, both physical and mental activity. The observation sheet is also used to record all activities of the lecturers during the learning process. It is expected that based on the results of the recording the complete implementation of the learning process can be identified in order to see the strengths and weaknesses that might arise. The result of recorded learning process is one of the reflection materials to improve the implementation of the learning process at the subsequent meetings. On the other hand, the evaluation instrument type of the learning journal is a form of reflection of the implementation of the learning process of each meeting and at the end of the semester. The learning journal is intended to trace the entire process of the learning to see the strength and weaknesses [20].

In relation to that matter, there are five similar studies on the importance of developing evaluation instrument to improve writing skills, process quality, and the quality of learning outcomes that support this development study, namely the studies by [21], [22], [23], [24], and [25]. In relation to those studies, there are differences in the approach used as the basis for the development of learning in the fifth evaluation instrument that research in this study. In the development of learning evaluation instrument, the constructivism approach was used in this study as the basis. It can be stated that although researchers use different approaches to develop evaluation instrument learning, but the point has relevance in terms of the function, namely improving the skills of literary 
appreciation, increasing the moral values of students, improving writing skills, improving the skills of critical reading, improving reasoning power of students, and improving the quality of the process and the quality of learning outcomes.

\section{CONCLUSION}

In this development research, the evaluation instruments of learning to write scientific papers with a constructivism approach were resulted. The evaluation instruments developed consisted of four types, namely the assessment rubrics, portfolios, observasion sheet, and learning journal. The evaluation instrument types of assessement rubric and portfolio assessment were used to evaluate student performance results, while the evaluation instrument types of observation sheets and learning journals were used to evaluate the implementation of the learning process.

These four types of the evaluation instruments were said to be reliable and valid because it had been through a series of tests, namely the practitioner test, expert tests, and field test. The practitioner test was conducted by the lecturer of the Scientific Writing course, the expert tests were carried out by the teaching method expert, subject matter experts, and learning evaluation expert, and the field tests are applied in small groups and large groups of students. Similarly, based on the results of the effectiveness testing of the development product they were declared to be effective.

This proves that the development product is essentially valid and effective and can be used to evaluate the learning of scientific writing, both the learning process and the learning outcome. The valid and effective development product can also be used to create the learning process that is capable of cultivating the sense of responsibility, mutual respect, mutual giving and receiving opinions of others, togetherness, honesty, exemplary, mutual help, mutual trust, tolerance, transparency, and democratic.

\section{ACKNOWLEDGMENT}

My thanks goes to the following individuals who have assisted the completion of this article. This article was a research competitive article granted by the Ministry of Research and Technology, and Higher Education. In connection with that, thank you first of all, I delivered to Ministry of Research and Technology, and Higher Education that has funded research to this article generates. LPPM Chairperson of Gorontalo State University that has approved the implementation of the study until it generates this article. I would like to thank to Dr. Fatmah AR. Umar, M.Pd as a member of the research team that was active in helping the retrieval of data, the implementation of the development process, the preparation of research report, until the realization of this article, to her I thank you. A team of experts and a team of practitioners who help correct evaluation instrument design, I thank you. Similarly, students involved in the pilot test of the effectiveness of product design and product development, I thank you. Colleagues who have helped to read and correct draft of this article, both derived from the field of science and of other disciplines, I thank you. Hopefully this article can help improve the quality of the learning process and results of scientific writing in college.

\section{REFERENCES}

[1] Jordaan, Heila. Language Teaching is No Panacea: A Theoretical Perspective and Critical Evaluation of Language in Education within The South African Context. South African Journal of Communication Disorders. Vol. 8 (3), pp 79-85 December 2011.

[2] Xueman Liu. Current Trends in Outcome Studies for Children with Hearing Loss and the Need to Establish a Comprehensive Framework of Measuring Outcomes in Children with Hearing Loss in China. Journal of Otology. Vol 11 (2), pp 43-36. 2016.

[3] Wijayanti. A. Pengembangan Autentic Assesment Berbasis Proyek dengan Pendekatan Saintifik untuk Meningkatkan Keterampilan Berpikir Ilmiah Mahasiswa. Jurnal Pendidikan IPA Indonesia. Vol. 3 (2), pp 102-108. 2014.

[4] Vibe Aarkrog_and Bjarne Wahlgren. International Journal for Research in Vocational Education and Training (IJRVET). Developing Schemas for Assessing Social Competences among Unskilled Young People. Vol. 4 (1), pp 47-68, 2017 April.

[5] Baylon, Edgar M. Effects of Classroom Assessment on the Critical Thinking and Academic Performance of Students. Asia Pacific Journal of Multidisciplinary Research. Vol. 2, (1), pp 205-208, February 2014.

[6] Kartowagiran, Badrun dan Amat Jaedun. Model Asesmen Autentik untuk Menilai Hasil Belajar Siswa Sekolah Menengah Pertama (SMP): Implementasi Asesmenautentik di SMP. Jurnal Penelitian dan Evaluasi Pendidikan. Vol. 20, (2), pp 131-141, Desember 2016.

[7] Sugiyanto dkk. Pengembangan Model Evaluasi Proses Pembelajaran Matematika di SMP Berdasarkan Kurikulum 2013. Jurnal Penelitian dan Evaluasi Pendidikan. Vol. 19 (1) hal 82-95, Juni 2015.

[8] Supriyadi. Pengembangan Model Pembelajaran Menulis Karya Ilmiah Dengan pendekatan Konstruktivisme. Jurnal Litera: Jurnal Penelitian Bahasa, Sastra, dan Pengajarannya. Vol. 14, (2), hal 361-375, Oktober 2015.

[9] Supriyadi. Pengembangan Model Pembelajaran Menulis Karya Ilmiah Dengan pendekatan Konstruktivisme. Jurnal Litera: Jurnal Penelitian Bahasa, Sastra, dan Pengajarannya. Vol. 14, (2), hal 361-375, Oktober 2015.

[10] Lesilolo, Herly Janet., Zamroni, dan Suyata. Jurnal Pembangunan Pendidikan: Fondasi dan Aplikasi. Kebebasan Siswa dalam Budaya Demokratis di Sekolah (Studi Multi Kasus di SMA Yogyakarta). Volume 3 (1) pp 11-18 Juni 2015.

[11] Thiagarajan, S., D.S. Semmel, \& M.I. Semmel. 1974. Instructional Development for Training Teachers of Expectional Children. Minneapolis, Minnesota: Leadership Training Institute/Special Education, University of Minnesota.

[12] Borg, W.R. and M.D. Gall. 1983. Educational Research: An Introduction, 4 th edition. London: Longman Inc. (http://psycnet.apa.org/psycinfo/ 1996-97171-000).

[13] Supriyadi. Pengembangan Model Pembelajaran Menulis Karya Ilmiah Dengan pendekatan Konstruktivisme. Jurnal Litera: Jurnal Penelitian Bahasa, Sastra, dan Pengajarannya. Vol. 14, (2), hal 361-375, Oktober 2015.

[14] Supriyadi. Pengembangan Model Pembelajaran Menulis Karya Ilmiah Dengan pendekatan Konstruktivisme. Jurnal Litera: Jurnal Penelitian Bahasa, Sastra, dan Pengajarannya. Vol. 14, (2), hal 361-375, Oktober 2015.

[15] Santoso, S. 2010. SPSS Versi 18.0 Mengolah Data Statistik secara Profesional. Jakarta: PT Elek Media Komputindo. (http://library.um.ac.id/free-contents/index.php/buku/ detail/spss-versi10-mengolah-data-statistik-secara-profesional-singgih-santoso10789.html). 
[16] Gömleksiz, Mehmet Nuri and Şenel Elaldi. Yapilandirmaci Yaklaşim Bağlaminda Yabanci dil Öğretimi. Turkish Studies-International Periodical for The Languages, Literature and History of Turkish or Turkic. Vol. 6(2), pp 443-454, Spring 2011.

[17] Gömleksiz, Mehmet Nuri and Şenel Elaldi. Yapilandirmaci Yaklaşim Bağlaminda Yabanci dil Öğretimi. Turkish Studies-International Periodical for The Languages, Literature and History of Turkish or Turkic. Vol. 6(2), pp 443-454, Spring 2011.

[18] Akinbobola, Akinyemi Olufunminiyi and Folashade Afolabi. Constructivist Practices through Guided Discovery Approach: The Effect on Students' Cognitive Achievements in Nigerian Senior Secondary School Physics. Bulgarian Journal of Science and Education Policy (BJSEP), Vol. 3(2), 2009.

[19] Vladi, Alma Cenkaj. Communicative language testing in ESP Context. Academic Journal of Business, Administration, Law and Social Sciences. Vol. 1(3), November 2015.

[20] Prihatini, Septimar, Djemari Mardapi, dan Sutrisno. Pengembangan Model Penilaian Akhlak Peserta Didik Madrasah Aliyah. Jurnal Penelitian dan Evaluasi Pendidikan. Vol. 17(2), hal. 347-368, 2013.

[21] Syamsi, Kastam. Model Perangkat Pembelajaran Menulis Berdasarkan Pendekatan Proses Genre bagi Siswa SMP. Litera, Vol. 11(2), hal. 288297, Oktober 2012.

[22] Wahyuni, Sri. Pengembangan Model Asesmen Otentik dalam Pembelajaran Keterampilan Berbahasa Indonesia Lisan di Sekolah Menengah Atas (SMA). Litera, Vol. 9(1), hal. 69-79, April 2013.

[23] Kiong, Tee Tze., Mohamed Nor Azhari Azman, Jailani Md Yunos, Yee Mei Heong, Mimi Mohaffyza Mohamad, Baharom Mohamad, and Widad Othman. The Development and Evaluation of the Qualities of Thinking Skills Module. Journal of Technical Education and Training. Vol. 5(1), pp 52-67, June 2013.

[24] Surya, Anesa dan Aman Aman. Developing Formative Authentic Assessment Instruments Based on Learning Trajectory for Elementary School. Developing Formative Authentic Assessment Instruments Based on Learning Trajectory for Elementary School. Research and Evaluation in Education. Vol. 2(1), pp 13-24, 2016.

[25] Wicaksono, Tulus Pamuji., Muhardjito Muhardjito, dan Titik Harsiati. Pengembangan Penilaian Sikap dengan Teknik Observasi, Self Assessment, dan Peer Assessment pada Pembelajaran Tematik Kelas V SDN Arjowinangun 02 Malang. Jurnal Pendidikan: Teori, Penelitian, dan Pengembangan. Vol. 1(2), hal. 45-51, Desember 2016. 